\title{
PSYCHOLOGICAL AND SOCIAL EFFECT OF PANDEMIC COVID-19 ON EDUCATION SYSTEM
}

*Dr. Bhawna Yadav

\begin{tabular}{l} 
Paper Received: 02.06.2020 / Paper Accepted: 04.07.2020 / Paper Published: 09.07.2020 \\
\hline Corresponding Author:Dr. Bhawna Yadav; Email: sangeety@gmail.com; doi:10.46360/globus.xxxxxxxx \\
\hline
\end{tabular}

\begin{abstract}
The present paper explains about the psychological and social effect of COVID 19 on education system. As the COVID-19 pandemic spreads around the world and across every country of the world. Since the end of 2019, until now, we know that the impact of the Covid-19 pandemic on the global economy is being intense and enormous. In the global aspect, there is no distinction of continent, country or even place. Not even economically in fact it effect on each and every aspect of the society. We are facing a global crisis- one that is killing people, spreading human suffering and upending people's lives. But this is more than a health crisis. It is human, psychological, economic and social crisis and its major effect generates on education system.
\end{abstract}

Keywords: Psychological, Sociological, Corona, Virus, Education, COVID-19.

\section{Introduction}

Mankind has observed various pandemic throughout the history where some of the were more disastrous than the others to the humans.We are observing a very tough time once again fighting an invisible enemy: the Novel COVID -19 Corona virus .Initially observed in the Wuhan province of China, now vastly spreading all over the world. Corona virus typically affect the respiratory tracts of birds and mammals, including humans .Doctors associate them with the common cold ,bronchitis, pneumonia, Severe Acute Respiratory Syndrome (SARS) and corona virus disease 2019 Corona virus usually cause the common cold ,though they can be responsible for more illness. Human history is observing a very strange time or a cytokine storm. This is when an infection triggers your immune system to flood your bloodstream inflammatory proteins called cytokines. They can kill tissue and damage your organsor a cytokine storm. This is when an infection triggers your immune system to flood your bloodstream inflammatory proteins called cytokines. They can kill tissue and damage your organs fighting an invisible enemy the novel COVID-19 Corona virus. Initially it was observed in the Wuhan province of China now fastly spreading all over the world. As this pandemic is very new and very less scientific material is available on the topic. Various paid journals and companies are offering free materials publishes about the Corona virus. Here in the short review we will discuss the articles about Corona virus.

Going to school is the best public policy tool available to raise skills. While school time can be fun and can rise social skills and social awareness, from an economic point of view the primary point of being in school is that it increases a child's ability. Even a relatively short time in school does this; even a relatively short period of missed school will have consequences for skill growth. But can we estimate how much the COVID-19 interruption will affect learning? Not very precisely, as we are in a new world; but we can use other studies to get an order of magnitude.

\section{Review of Literature}

Gupta, R and Agarwal, N et.al. (2020) explains Artificial intelligence is programmed on computers to depict human intelligence. It has created a huge hype and has evolved to 
revolutionize almost every profession including legal sector. New lawful simulated AI programming software like Ross intelligence and Catalyst along with Machine Learning and Natural Language Processing give viable fight goals, better legitimate clearness, and better permission to justice and new difficulties to ordinary law firms offering legal assistance utilizing leveraged cohort correlate model. Also, AI enabled lawyer bots are performing tasks that normally requires human intellect and needs to be performed by lawyers. In such a situation, a question strikeWill these lawyer bots replace human lawyers? This question becomes all the more important in the present scenario when the whole globe is facing challenges imposed by global pandemic "Covid 19". How is COVID-19 going to change the justice delivery system, and what does it look like? Therefore, this study is conducted to evaluate the role of artificial intelligence in transforming the justice delivery system post Covid-19. The study tries to examine the various areas in which AI is affecting the legal profession, evaluate the extent of its impact on the legal employment, assess the tasks in legal sector which cannot be undertaken by AI, and discuss the legal issues in the implementation of AI. The study also suggests the way forward with regards to the future of legal sector to help practitioners and researchers.[1, 2, 3, 4, 11]

Dr. Shakila Shamsu shed light on the use of technology for education should not be seen as an outcome of the pandemic, but as an idea that has been continuing for several years. She corroborated this point by outlining the efforts of the National Mission on Education through ICT which was a strong recommendation of the 11 th five-year plan. She explained how the Satellite Instructional Television Experiment in the 1970s and educational broadcasting that happened over the radio were ways in which technology was used in the field of education, giving "equitable access" to all those learning through those mediums. The Union HRD Ministry had launched a TV channel for students to take online courses and at present 15 million students are enrolled with it. It also launched a subsidiary direct-to-home channel in 2019, called Swayam Prabha. The number of viewers has been doubled compared to its parent channel. She believed that the reason India is not able to transition swiftly from face-to-face education to remote learning is the lack of institutional preparedness and accessibility by students to the new mode of delivering classes. She also suggested that "higher education institutions should begin to construct an academic plan of action." Therefore, there is a "need to guide institutions, faculty and students to repurpose e-content in a manner that fits into the curricula for achieving the desired learning objectives of that particular course". She concluded her opening statements by saying that to reach a larger audience, it is essential econtent should be made available in regional languages.

\section{Corona Virus and Education}

Sometime in the second week of March, state governments across the country began shutting down schools and colleges temporarily as a measure to contain the spread of the novel corona virus. It's close to a month and there is no certainty when they will reopen. This is a crucial time for the education sector-board examinations, nursery school admissions, entrance tests of various universities and competitive examinations, among others, are all held during this period. As the days pass by with no immediate solution to stop the outbreak of Covid-19, school and university closures will not only have a short-term impact on the continuity of learning for more than 285 million young learners in India but also engender farreaching economic and societal consequences.

The structure of schooling and learning, including teaching and assessment methodologies, was the first to be affected by these closures. Only a handful of private schools could adopt online teaching methods. Their low-income private and government school counterparts, on the other hand, have completely shut down for not having access to e-learning solutions. The students, in addition to the missed opportunities for learning, no longer have access to healthy meals during this time and are subject to economic and social stress.

The bigger concern, however, on everybody's mind is the effect of the disease on the employment rate. Recent graduates in India are fearing withdrawal of job offers from corporates because of the current situation. The Centre for Monitoring Indian Economy's estimates on unemployment shot up from $8.4 \%$ in mid-March to $23 \%$ in early April and the urban unemployment rate to $30.9 \%$.

Needless to say, the pandemic has transformed the centuries-old, chalk-talk teaching model to one driven by technology. This disruption in the delivery of education is pushing policymakers to figure out how to drive engagement at scale while ensuring inclusive e-learning solutions and tackling the digital divide.

One, immediate measures are essential to ensure continuity of learning in government schools and 
universities. Open-source digital learning solutions and Learning Management Software should be adopted so teachers can conduct teaching online. The DIKSHA platform, with reach across all states in India, can be further strengthened to ensure accessibility of learning to the students.

Two, inclusive learning solutions, especially for the most vulnerable and marginalized, need to be developed. With a rapid increase of mobile internet users in India, which is expected to reach $85 \%$ households by 2024, technology is enabling ubiquitous access and personalization of education even in the remotest parts of the country. This can change the schooling system and increase the effectiveness of learning and teaching, giving students and teachers multiple options to choose from. Many aspirational districts have initiated innovative, mobile-based learning models for effective delivery of education, which can be adopted by others.

Three, strategies are required to prepare the higher education sector for the evolving demand-supply trends across the globe-particularly those related to the global mobility of students and faculty and improving the quality of and demand for higher studies in India. Further, immediate measures are required to mitigate the effects of the pandemic on job offers, internship programs, and research projects.

Four, it is also important to reconsider the current delivery and pedagogical methods in school and higher education by seamlessly integrating classroom learning with e-learning modes to build a unified learning system. The major challenge in EDTech reforms at the national level is the seamless integration of technology in the present Indian education system, which is the most diverse and largest in the world with more than 15 lakh schools and 50,000 higher education institutions. Further, it is also important to establish quality assurance mechanisms and quality benchmark for online learning developed and offered by India HEIs as well as e-learning platforms (growing rapidly). Many e-learning players offer multiple courses on the same subjects with different levels of certifications, methodology and assessment parameters. So, the quality of courses may differ across different e-learning platforms.

Five, Indian traditional knowledge is well known across the globe for its scientific innovations, values, and benefits to develop sustainable technologies and medicines. The courses on Indian traditional knowledge systems in the fields of yoga, Indian medicines, architecture, hydraulics, ethnobotany, metallurgy and agriculture should be integrated with a present-day mainstream university education to serve the larger cases of humanity.

In this time of crisis, a well-rounded and effective educational practice is what is needed for the capacity-building of young minds. It will develop skills that will drive their employability, productivity, health, and well-being in the decades to come, and ensure the overall progress of India.

\section{Four Positive Changes in Education Due To Covid-19}

Any change that is so disruptive is also likely to bring with it some new opportunities that will transform the higher education system worldwide and especially in a country like India which is planning to bring about a planned reform in this sector.Some of the key areas are following:

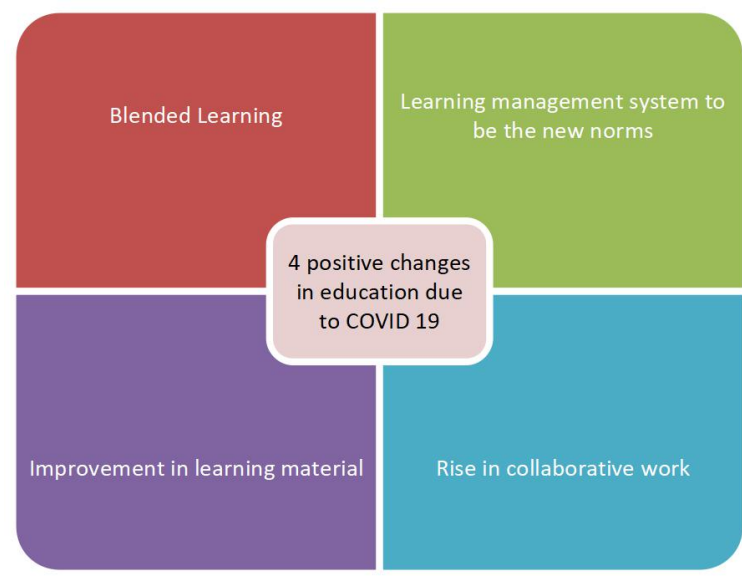

\section{Rise in Blended Learning}

Universities and colleges will shift to a model of blended learning where both face to face delivery along with an online model will become a norm. This will require all teachers to become more technology savvy and go through some training to bring themselves to the level that would be required.

New ways of delivery and assessments of learning outcomes will have to be adopted which opens immense opportunities for a major transformation in the area of curriculum development and pedagogy.

\section{Learning Management Systems to Be the New Norm}

A great opportunity will open up for those companies that have been developing and strengthening learning management systems for use by universities and colleges This has the potential to grow at a very fast pace but will have to be priced appropriately for use by all institutions. 


\section{Improvement in Learning Material}

There is a great opportunity for universities and colleges to start improving the quality of the learning material that is used in the teaching and learning process.

Since blended learning will be the new format of learning there will be a push to find new ways to design and deliver quality content especially due to the fact that the use of learning management systems will bring about more openness and transparency in academics.

\section{Rise in Collaborative Work}

The teaching community to a large extent has been very insulated and more so in a country like India. There is a new opportunity where collaborative teaching and learning can take on new forms and can even be monetized.

Faculty members/ teachers can deliver online courses to even students from competing institutions. Collaborations can also happen among faculty/teachers across the nation to benefit from each other.

Finally, it is expected that there will be a massive rise in teleconferencing opportunities which can also have a negative impact on the travel.

\section{Four Negative Impacts of Covid-19 on Education}

There are a number of areas of potential risks for global educationHere are 4 negative impacts of COVID on Education.

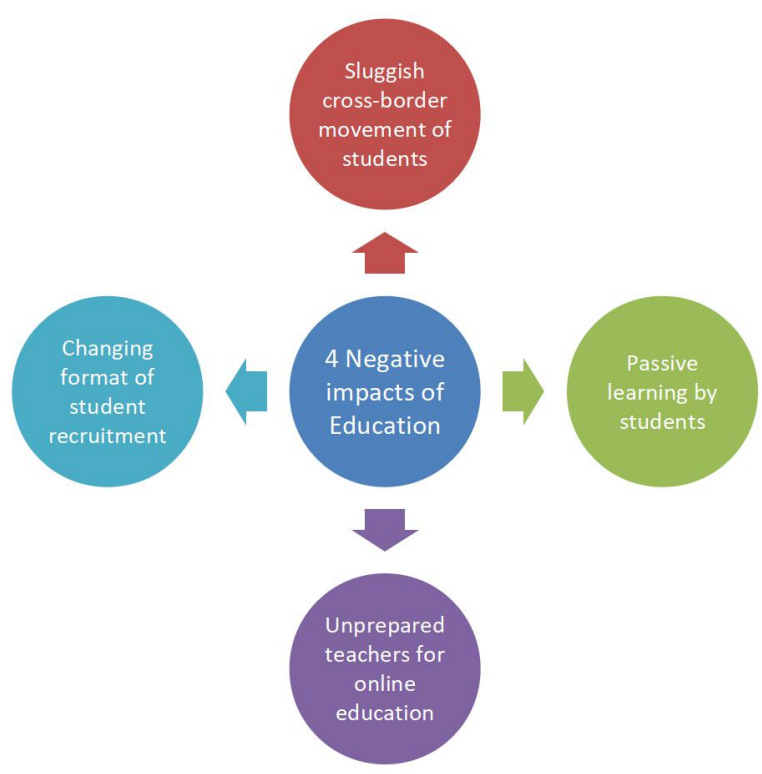

\section{Sluggish Cross-Border Movement of Students}

Universities in many countries such as Australia, UK, New Zealand, and Canada are highly dependent on the movement of students from China and India.

It is becoming more and more clear that this crossborder movement of students will take a beating at least for the next two to three years and will lead to a major financial risk for universities in these countries who are already under financial pressure. Many parents will avoid sending students abroad for higher education due to high risk from the pandemic.

\section{Passive Learning by Students}

The sudden shift to online learning without any planning -- especially in countries like India where the backbone for online learning was not ready and the curriculum was not designed for such a format - has created the risk of most of our students becoming passive learners and they seem to be losing interest due to low levels of attention span.

Added to this is that we may be leaving a large proportion of the student population untouched due to the digital divide that is part of many developing nations including India.

We are now beginning to realize that online learning could be dull as it is creating a new set of passive learners which can pose new challenges.

\section{Unprepared Teachers for Online Education}

Online learning is a special kind of methodology and not all teachers are good at it or at least not all of them were ready for this sudden transition from face to face learning to online learning.

Thus, most of the teachers are just conducting lectures on video platforms such as Zoom which may not be real online learning in the absence of a dedicated online platform specifically designed for the purpose.

There is a risk that in such a situation, learning outcomes may not be achieved and it may be only resulting in engaging the students.

\section{Changing Format of Student Recruitment}

Universities and colleges worldwide are facing a major risk in the area of student recruitment and retention.

The risk of losing students is so high that they will need to re-look at their admission practices, admission criteria and the overall recruitment 
process itself which will include, new methods of outreach and application process itself.

\section{Analysis of Data}

As per the title we tried to assess that there is Psychological effect of COVID 19 on secondary school students. Hence, we asked the respondents whether they agree that there is Psychological effect of COVID 19 on secondary school students. In this regard we got the response as mentioned below-

Table 1: Response for the Question Number 1

\begin{tabular}{|l|l|l|}
\hline S. No. & Parameters & $\begin{array}{l}\text { Number } \\
\text { respondents }\end{array}$ \\
\hline 1 & Strongly Agree & 45 \\
\hline 2 & Agree & 12 \\
\hline 3 & Partially Agree & 13 \\
\hline 4 & Not sure & 8 \\
\hline 5 & $\begin{array}{l}\text { Partially } \\
\text { Disagree }\end{array}$ & 6 \\
\hline 6 & Disagree & 4 \\
\hline 7 & $\begin{array}{l}\text { Strongly } \\
\text { Disagree }\end{array}$ & 12 \\
\hline
\end{tabular}

Chart 1: Response for the Question Number 1

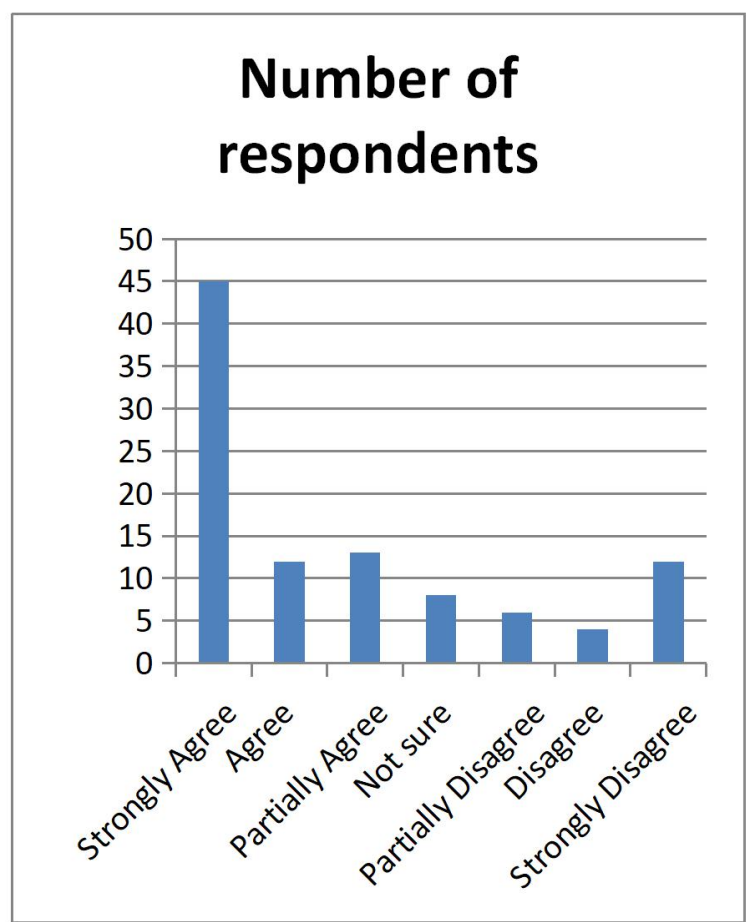

we asked the respondents whether online teaching during COVID 19 is effective for secondary school students? In this regard all the respondents were not similarly responsive. Therefore, overall response is mentioned below-
Table 2: Response for the Question Number 2

\begin{tabular}{|l|l|l|}
\hline S. No. & Parameters & $\begin{array}{l}\text { Number of } \\
\text { respondents }\end{array}$ \\
\hline 1 & Strongly Agree & 15 \\
\hline 2 & Agree & 12 \\
\hline 3 & Partially Agree & 13 \\
\hline 4 & Not sure & 28 \\
\hline 5 & $\begin{array}{l}\text { Partially } \\
\text { Disagree }\end{array}$ & 8 \\
\hline 6 & Disagree & 12 \\
\hline 7 & $\begin{array}{l}\text { Strongly } \\
\text { Disagree }\end{array}$ & 12 \\
\hline
\end{tabular}

Chart 2: Response for the Question Number 2

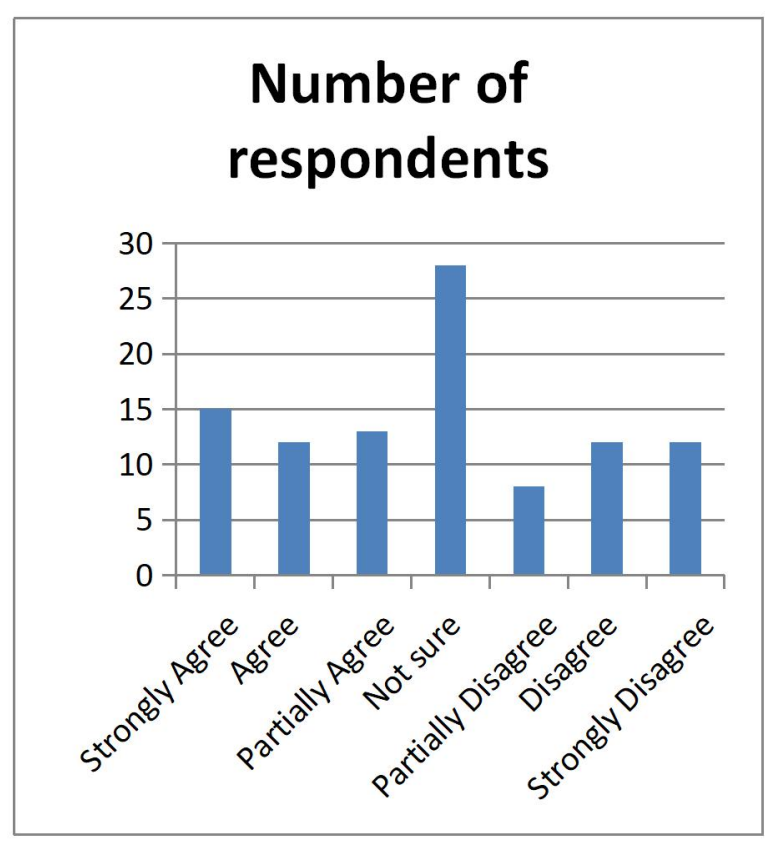

We further asked the respondents whether they agree that lack of physical activity during COVID 19 effects psychologically secondary school students? In this regard all the respondents were not similarly responsive. Therefore, overall response is mentioned below-

Table 3: Response for the Question Number 3

\begin{tabular}{|l|l|l|}
\hline S. No. & Parameters & $\begin{array}{l}\text { Number } \\
\text { respondents }\end{array}$ \\
\hline 1 & Strongly Agree & 23 \\
\hline 2 & Agree & 12 \\
\hline 3 & Partially Agree & 20 \\
\hline 4 & Not sure & 18 \\
\hline 5 & $\begin{array}{l}\text { Partially } \\
\text { Disagree }\end{array}$ & 11 \\
\hline 6 & Disagree & 4 \\
\hline 7 & $\begin{array}{l}\text { Strongly } \\
\text { Disagree }\end{array}$ & 12 \\
\hline
\end{tabular}




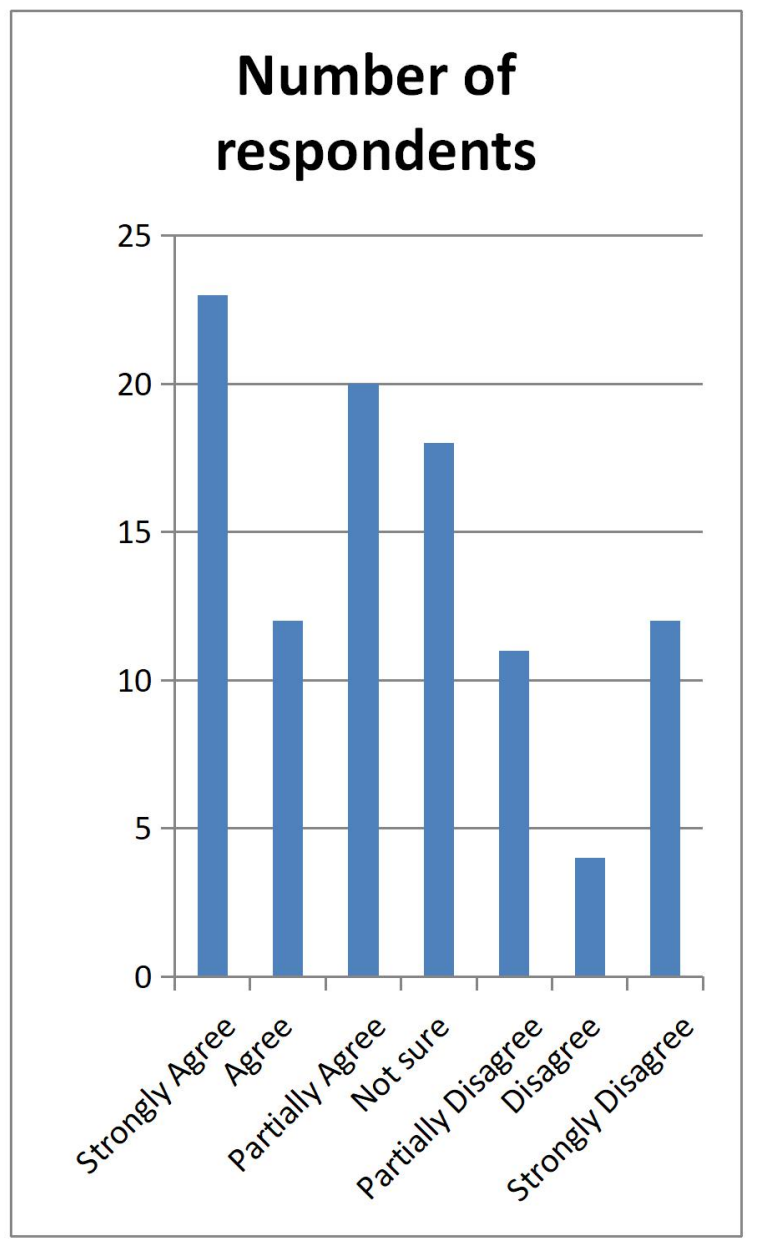

When we asked the respondents whether resources for effective online education are available for secondary school students during COVID19, we got the feedback as given below-

Table 4: Response for the Question Number 4

\begin{tabular}{|l|l|l|}
\hline S. No. & Parameters & $\begin{array}{l}\text { Number } \\
\text { respondents }\end{array}$ \\
\hline 1 & Strongly Agree & 34 \\
\hline 2 & Agree & 22 \\
\hline 3 & Partially Agree & 10 \\
\hline 4 & Not sure & 7 \\
\hline 5 & $\begin{array}{l}\text { Partially } \\
\text { Disagree }\end{array}$ & 11 \\
\hline 6 & Disagree & 4 \\
\hline 7 & $\begin{array}{l}\text { Strongly } \\
\text { Disagree }\end{array}$ & 12 \\
\hline
\end{tabular}

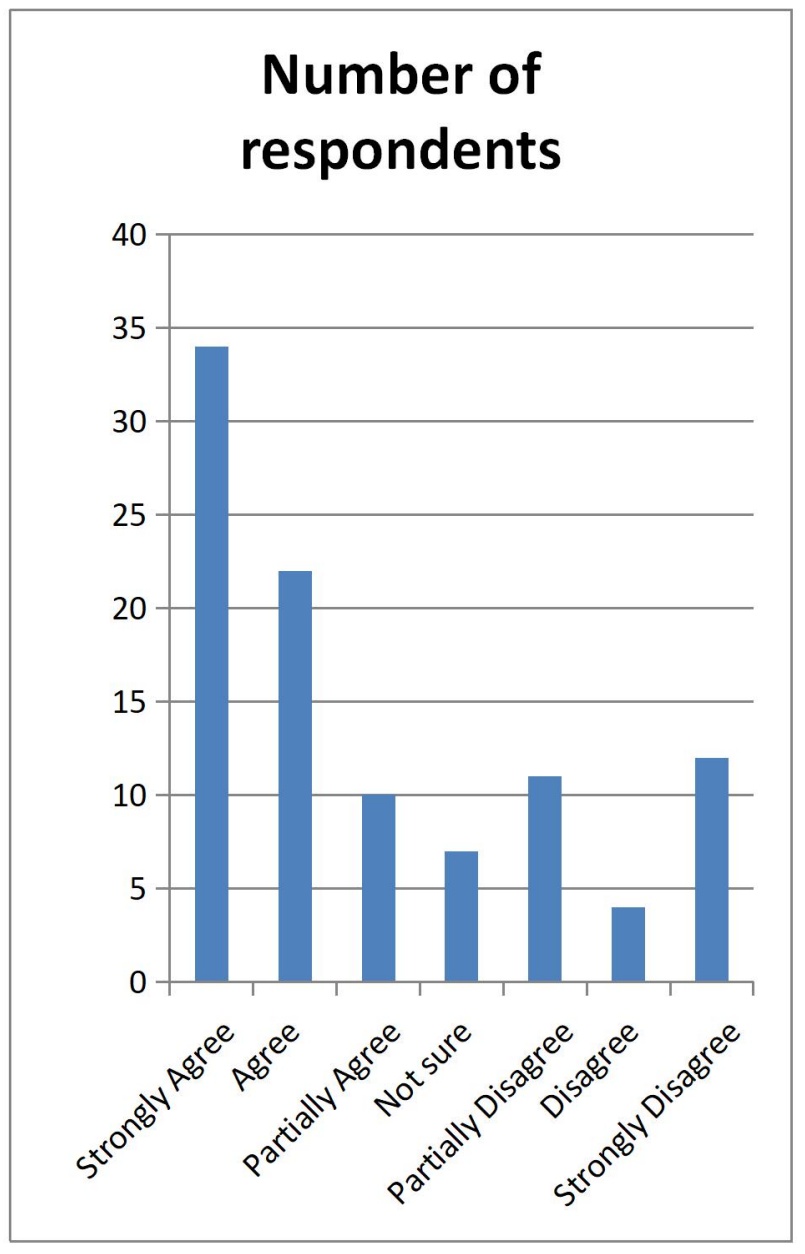

We further asked the respondents whether they agree secondary school students taking serious online education system during COVID 19. In this regard all the respondents were not similarly responsive. Therefore, overall response is mentioned below-

Table 5: Response for the Question Number 5

\begin{tabular}{|l|l|l|}
\hline S. No. & Parameters & $\begin{array}{l}\text { Number } \\
\text { respondents }\end{array}$ \\
\hline 1 & Strongly Agree & 10 \\
\hline 2 & Agree & 12 \\
\hline 3 & Partially Agree & 3 \\
\hline 4 & Not sure & 10 \\
\hline 5 & $\begin{array}{l}\text { Partially } \\
\text { Disagree }\end{array}$ & 16 \\
\hline 6 & Disagree & 14 \\
\hline 7 & $\begin{array}{l}\text { Strongly } \\
\text { Disagree }\end{array}$ & 35 \\
\hline
\end{tabular}




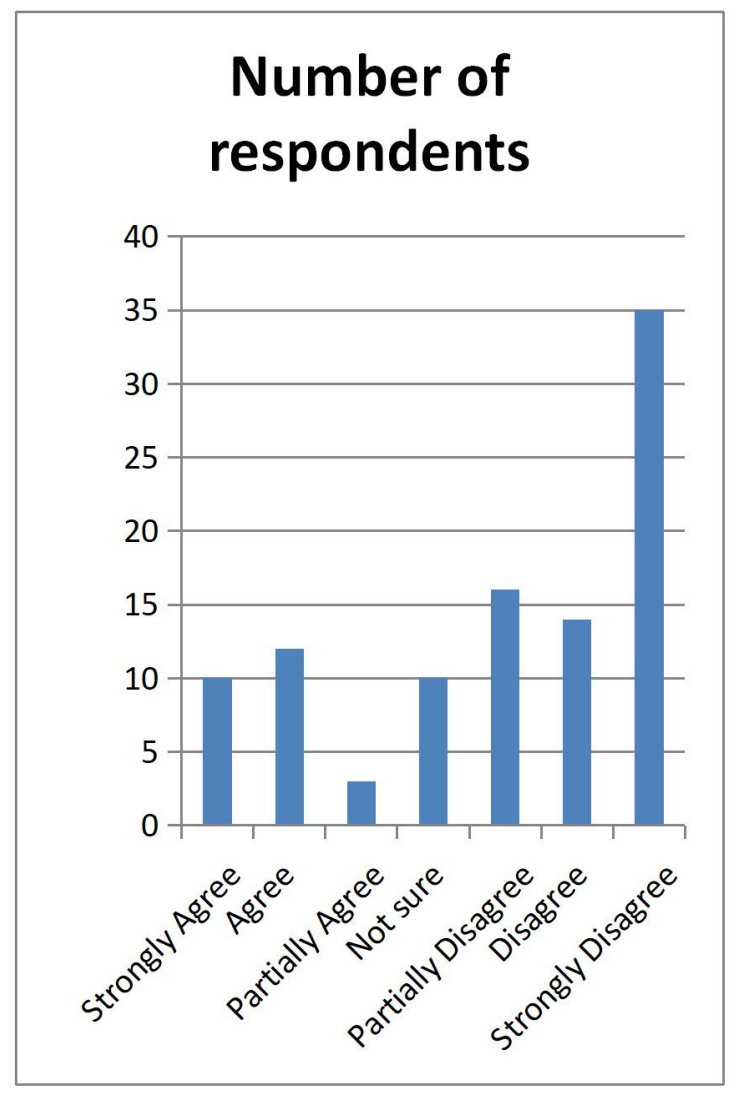

we asked the respondents whether they assume that COVID 19 affects socially secondary school students. In this regard all the respondents were not similarly responsive. Therefore, overall response is mentioned below-

Table 6: Response for the Question Number 6

\begin{tabular}{|l|l|l|}
\hline S. No. & Parameters & $\begin{array}{l}\text { Number } \\
\text { respondents }\end{array}$ \\
\hline 1 & Strongly Agree & 24 \\
\hline 2 & Agree & 12 \\
\hline 3 & Partially Agree & 9 \\
\hline 4 & Not sure & 28 \\
\hline 5 & $\begin{array}{l}\text { Partially } \\
\text { Disagree }\end{array}$ & 6 \\
\hline 6 & Disagree & 9 \\
\hline 7 & $\begin{array}{l}\text { Strongly } \\
\text { Disagree }\end{array}$ & 12 \\
\hline
\end{tabular}

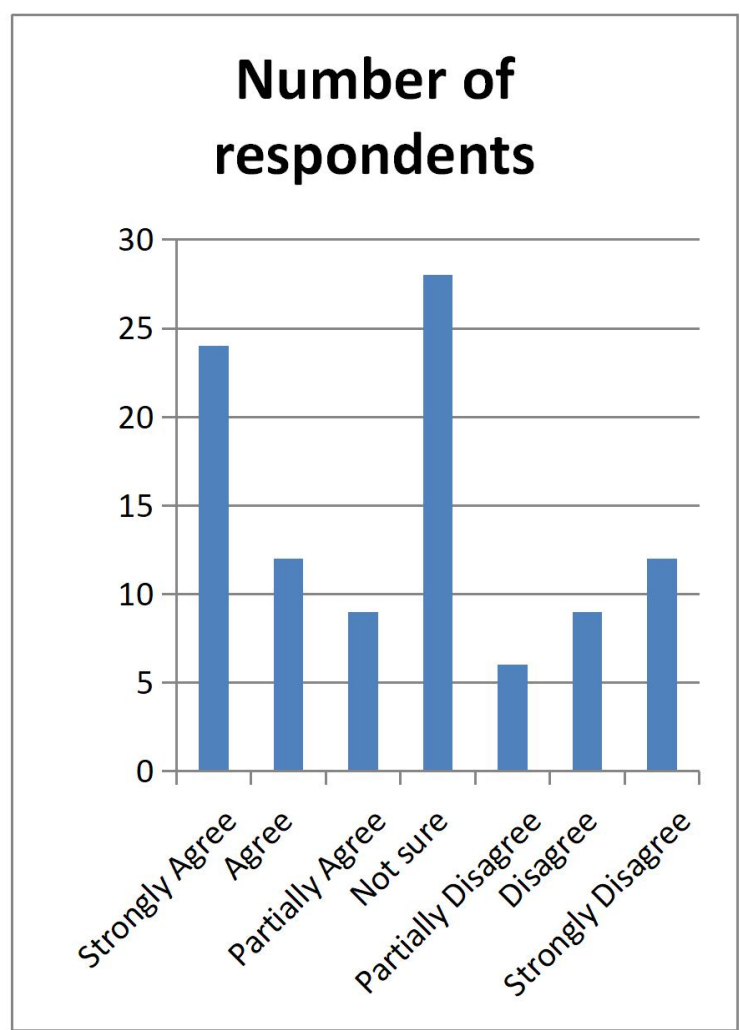

We further asked the respondents whether they agree that pandemic COVID 19 significantly disrupted secondary education. In this regard all the respondents were not similarly responsive. Therefore, overall response is mentioned below-

Table 7: Response for the Question Number 7

\begin{tabular}{|l|l|l|}
\hline S. No. & Parameters & $\begin{array}{l}\text { Number } \\
\text { respondents }\end{array}$ \\
\hline 1 & Strongly Agree & 43 \\
\hline 2 & Agree & 12 \\
\hline 3 & Partially Agree & 10 \\
\hline 4 & Not sure & 8 \\
\hline 5 & $\begin{array}{l}\text { Partially } \\
\text { Disagree }\end{array}$ & 11 \\
\hline 6 & Disagree & 4 \\
\hline 7 & $\begin{array}{l}\text { Strongly } \\
\text { Disagree }\end{array}$ & 12 \\
\hline
\end{tabular}




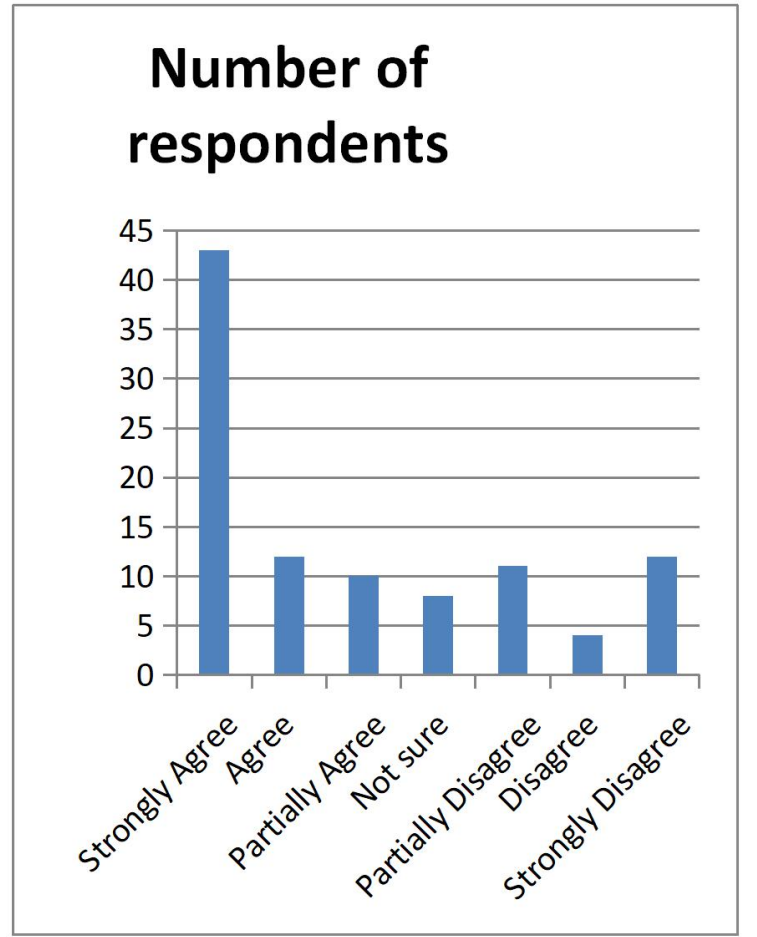

we asked the respondents whether they agree that online teaching positively affect the secondary school students. In this regard all the respondents were not similarly responsive. Therefore, overall response is mentioned below-

Table 8: Response for the Question Number 8

\begin{tabular}{|l|l|l|}
\hline S. No. & Parameters & $\begin{array}{l}\text { Number } \\
\text { respondents }\end{array}$ \\
\hline 1 & Strongly Agree & 11 \\
\hline 2 & Agree & 12 \\
\hline 3 & Partially Agree & 35 \\
\hline 4 & Not sure & 29 \\
\hline 5 & $\begin{array}{l}\text { Partially } \\
\text { Disagree }\end{array}$ & 6 \\
\hline 6 & Disagree & 5 \\
\hline 7 & $\begin{array}{l}\text { Strongly } \\
\text { Disagree }\end{array}$ & 12 \\
\hline
\end{tabular}

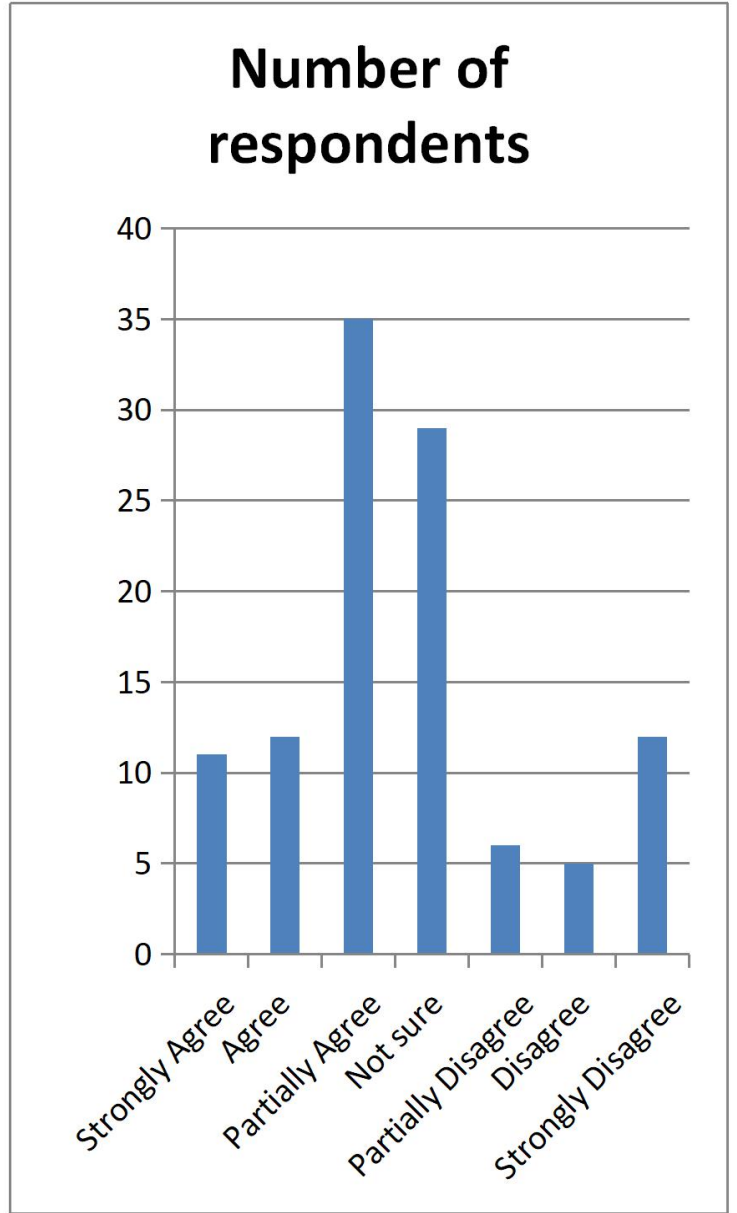

We further asked the respondents whether they agree that online teaching improves skills of secondary school students.In this regard all the respondents were not similarly responsive. Therefore, overall response is mentioned below-

Table 9: Response for the Question Number 9

\begin{tabular}{|l|l|l|}
\hline S. No. & Parameters & $\begin{array}{l}\text { Number of } \\
\text { respondents }\end{array}$ \\
\hline 1 & Strongly Agree & 14 \\
\hline 2 & Agree & 12 \\
\hline 3 & Partially Agree & 10 \\
\hline 4 & Not sure & 28 \\
\hline 5 & $\begin{array}{l}\text { Partially } \\
\text { Disagree }\end{array}$ & 16 \\
\hline 6 & Disagree & 14 \\
\hline 7 & $\begin{array}{l}\text { Strongly } \\
\text { Disagree }\end{array}$ & 6 \\
\hline
\end{tabular}




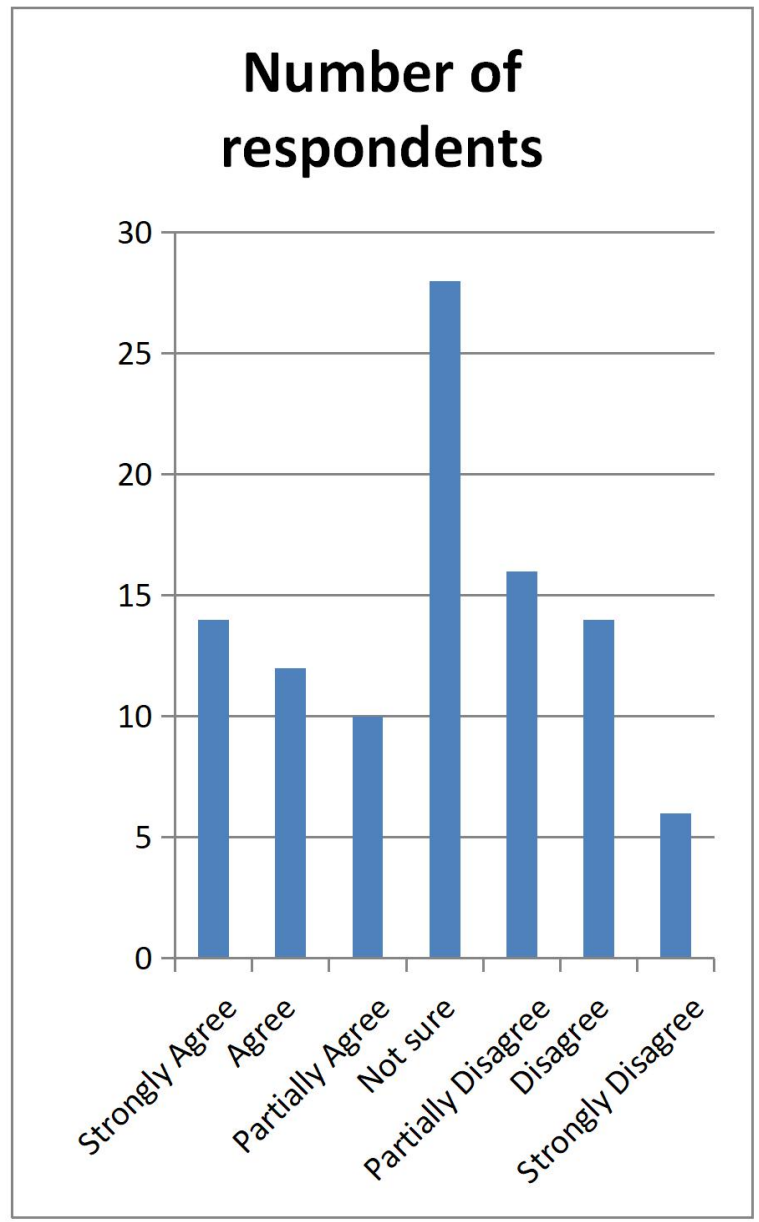

At last we asked the respondents whether they agree that COVID 19 socially affects secondary education. In this regard all the respondents were not similarly responsive. Therefore, overall response is mentioned below-

Table 10: Response for the Question Number 10

\begin{tabular}{|l|l|l|}
\hline S. No. & Parameters & $\begin{array}{l}\text { Number } \\
\text { respondents }\end{array}$ \\
\hline 1 & Strongly Agree & 34 \\
\hline 2 & Agree & 12 \\
\hline 3 & Partially Agree & 9 \\
\hline 4 & Not sure & 11 \\
\hline 5 & $\begin{array}{l}\text { Partially } \\
\text { Disagree }\end{array}$ & 14 \\
\hline 6 & Disagree & 8 \\
\hline 7 & $\begin{array}{l}\text { Strongly } \\
\text { Disagree }\end{array}$ & 12 \\
\hline
\end{tabular}

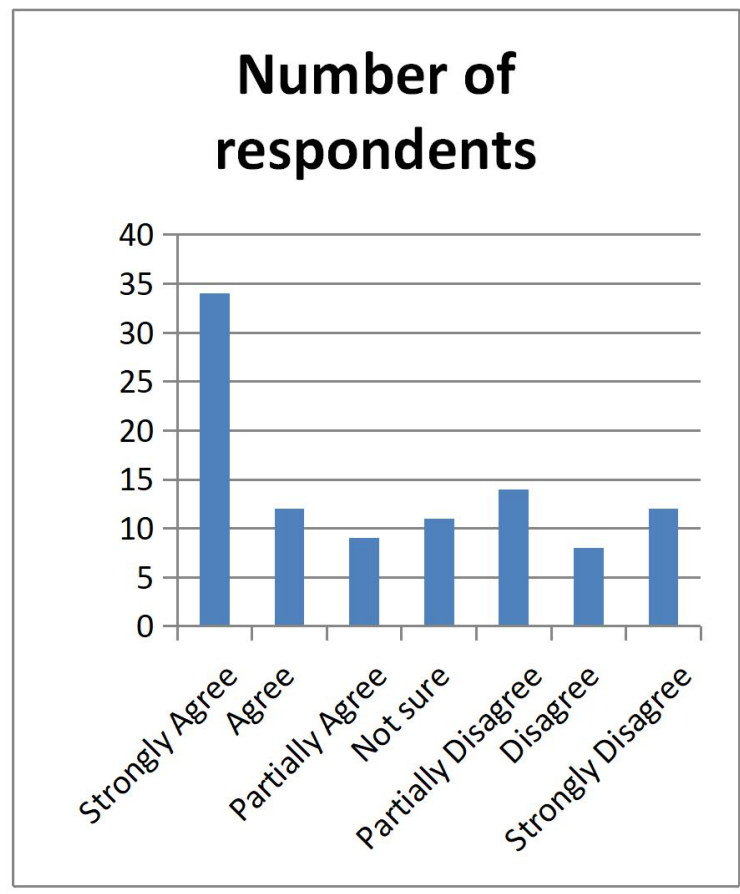

\section{Conclusion}

Families are central to education and are widely agreed to provide major inputs into a child's learning, as described by Bjorklund and Salvanes (2011). The current global-scale expansion in home schooling might at first thought be seen quite positively, as likely to be effective. But typically, this role is seen as a complement to the input from school. Parents supplement a child's maths learning by practising counting or highlighting simple maths problems in everyday life; or they illuminate history lessons with trips to important monuments or museums. Being the prime driver of learning, even in conjunction with online materials, is a different question; and while many parents round the world do successfully school their children at home, this seems unlikely to generalise over the whole population.

The closure of schools, colleges and universities not only interrupts the teaching for students around the world; the closure also coincides with a key assessment period and many exams have been postponed or cancelled. Internal assessments are perhaps thought to be less important and many have been simply cancelled. But their point is to give information about the child's progress for families and teachers. The loss of this information delays the recognition of both high potential and learning difficulties and can have harmful longterm consequences for the child. Andersen and Nielsen (2019) look at the consequence of a major IT crash in the testing system in Denmark. As a result of this, some children could not take the 
test. The authors find that participating in the test increased the score in a reading test two years later by $9 \%$ of a standard deviation, with similar effects in mathematics. These effects are largest for children from disadvantaged backgrounds.

It is also possible that some students' careers might benefit from the interruptions. For example, in Norway it has been decided that all 10th grade students will be awarded a high-school degree. And Maurin and McNally (2008) show that the 1968 abandoning of the normal examination procedures in France (following the student riots) led to positive long-term labour market consequences for the affected cohort.

\section{References}

1. Agarwal, Nidhi, (2018). "A study of innovations in instructional strategies and designs for quality enrichment in Higher Education". Cosmos: An International Journal of Art \& Higher Education, 7(2), ISSN: 23198966.

2. Agarwal, Nidhi and Gupta, Jayanta Das, (2018). "Impact of high school on social development". International Journal of Advance Research and Development, 3(4), 187-188, http://doi:10.5281/zenodo.3813532.

3. Agarwal, Nidhi and Kumar, Puneet (2009). "Reflection on the new Innovations for maximizing the learning in Teacher of Mathematics", International Journal Educational Herald, 38(2):41.

4. Agarwal, Nidhi and Kumar, Puneet, (2009). "Role of Information Technology in Education", AICTE Sponsored National conference on Information Integrity \& Supply chain Management Abstracts Proceeding, Book World Publisher, Dehradun, Pp. 18.

5. Agarwal, Nidhi and Shiju P.S., (2018). "A Study on Content Generation for Internet Usage". International Journal of Advanced Research and Development, 3(2): 1380-1382, http://doi: 10.5281/zenodo.3764806.

6. Agarwal, Nidhi and Verma, Monika, (2019). "A Study on Taxonomy of Innovations". Globus An International Journal of Management \& IT, 11(1); 57-64.

7. Andersen, S.C. and Nielsen, H.S., (2019). Learning from Performance Information. Journal of Public Administration Research and Theory.

8. Bjorklund, A. and Salvanes, K., (2011). "Education and Family Background: Mechanisms and Policies", in E Hanushek, S Machin and L Woessmann (eds), Handbook of the Economics of Education, Vol. 3.

9. Burgess, S. and Greaves, E., (2013). "Test Scores, Subjective Assessment, and Stereotyping of Ethnic Minorities". Journal of Labor Economics, 31(3): 535-576.

10. Carlsson, M., Dahl, G.B., Ockert, B. and Rooth, D., (2015). "The Effect of Schooling on Cognitive Skills". Review of Economics and Statistics, 97(3): 533-547.

11. Chandra, G., Gupta, R. and Agarwal, N. (2020). Role of Artificial Intelligence in Transforming the Justice Delivery System in COVID 19 Pandemic. International Journal on Emerging Technologies, 11(3): 344-350.

12. Maurin, E. and McNally, S., (2008). "Vive la revolution! Long-term educational returns of 1968 to the angry students". Journal of Labor Economics, 26(1): 1-33.

\section{Annexure}

Questionnaire

Q1. Do you agree that there is Psychological effect of COVID 19 on secondary school students?
a) Strongly Agree
b) Agree
c) Partially Agree
d) Not sure
e) Partially Disagree
f) Disagree
g) Strongly Disagree

Q2. Do you agree that online teaching during COVID 19 is effective for secondary school students?
a) Strongly Agree
b) Agree
c) Partially Agree
d) Not sure
e) Partially Disagree
f) Disagree
g) Strongly Disagree 
Q3. Do you agree that lack of physical activity during COVID 19 effects psychologically secondary school students?
a) Strongly Agree
b) Agree
c) Partially Agree
d) Not sure
e) Partially Disagree
f) Disagree
g) Strongly Disagree

Q4. Do you agree that resources for effective online education are available for secondary school students during COVID19?
a) Strongly Agree
b) Agree
c) Partially Agree
d) Not sure
e) Partially Disagree
f) Disagree
g) Strongly Disagree

Q5. Do you agree that secondary school students taking serious online education system during COVID 19?
a) Strongly Agree
b) Agree
c) Partially Agree
d) Not sure
e) Partially Disagree
f) Disagree
g) Strongly Disagree

Q6. Do you assume that COVID 19 affects socially secondary school students?
a) Strongly Agree
b) Agree
c) Partially Agree
d) Not sure
e) Partially Disagree
f) Disagree
g) Strongly Disagree

Q7. Do you agree that pandemic COVID 19 significantly disrupted secondary education?
a) Strongly Agree
b) Agree
c) Partially Agree
d) Not sure
e) Partially Disagree
f) Disagree
g) Strongly Disagree

Q8. Do you agree that online teaching positively affect the secondary school students?
a) Strongly Agree
b) Agree
c) Partially Agree
d) Not sure
e) Partially Disagree
f) Disagree
g) Strongly Disagree

Q9. Do you agree that online teaching improves skills of secondary school students?
a) Strongly Agree
b) Agree
c) Partially Agree 

d) Not sure
e) Partially Disagree
f) Disagree
g) Strongly Disagree

Q10. Do you agree that COVID 19 socially affects secondary education?
a) Strongly Agree
b) Agree
c) Partially Agree
d) Not sure
e) Partially Disagree
f) Disagree
g) Strongly Disagree 